\title{
Preparing polished crystal slices with high precision orientation
}

\author{
Mathiesen, S. Ipsen; Gerward, Leif; Pedersen, 0.
}

\section{Published in:}

Review of Scientific Instruments

Link to article, DOI:

$10.1063 / 1.1686604$

Publication date:

1974

\section{Document Version}

Publisher's PDF, also known as Version of record

Link back to DTU Orbit

Citation (APA):

Mathiesen, S. I., Gerward, L., \& Pedersen, O. (1974). Preparing polished crystal slices with high precision orientation. Review of Scientific Instruments, 45(2), 278-279. https://doi.org/10.1063/1.1686604

\section{General rights}

Copyright and moral rights for the publications made accessible in the public portal are retained by the authors and/or other copyright owners and it is a condition of accessing publications that users recognise and abide by the legal requirements associated with these rights.

- Users may download and print one copy of any publication from the public portal for the purpose of private study or research.

- You may not further distribute the material or use it for any profit-making activity or commercial gain

- You may freely distribute the URL identifying the publication in the public portal

If you believe that this document breaches copyright please contact us providing details, and we will remove access to the work immediately and investigate your claim 


\title{
Preparing polished crystal slices with high precision orientation
}

\author{
S. Ipsen Mathiesen, L. Gerward, and O. Pedersen
}

Laboratory of Applied Physics III, Building 307, Technical University of Denmark, DK-2800 Lyngby, Denmark

(Received 20 March 1973; and in final form, 4 May 1973)

\begin{abstract}
A polishing procedure is described which utilizes a high precision Laue technique for crystal orientation. Crystal slices with their final polished surfaces parallel to a crystallographic plane within $0.02^{\circ}$ can be prepared.
\end{abstract}

\section{INTRODUCTION}

Several experiments in crystal physics require a sample with its surfaces parallel to a high degree of accuracy to a specified crystallographic plane. The $x$-ray Laue technique generally used for orientation can be considerably improved if the normal to the crystallographic plane is a symmetry axis. ${ }^{1}$ In this case deviations less than $0.01^{\circ}$ from the ideal orientation can be detected using symmetry in intensity, as well as position of characteristic line spots in the Laue pattern.

The present paper describes an equipment for preparing oriented crystal slices. The equipment was designed to meet the requirement that the high accuracy mentioned above should be utilized throughout the polishing procedure. The final polished surfaces of a sample should be parallel to a crystallographic symmetry plane within a few hundredths of a degree.

\section{EXPERIMENTAL PROCEDURE}

Figure 1 shows the polishing jig standing on the lapping plate. A crystal slice (S), cut within a few tenths of a degree from the desired orientation, is mounted onto the sample holder. The surface to be polished is determined by an optically flat reference surface $(\mathrm{R})$ of a glass ring attached to the outer holder $(\mathrm{O})$ of the jig. Three adjustment screws (A) are used to correct the orientation of the sample.

If the sample is to be $x$-ray oriented while it is mounted in the polishing jig, provisions must be made so that the reference surface becomes perpendicular to the incident $\mathrm{x}$-ray beam. This is achieved by mounting the complete polishing jig in a preadjusted holder (called the jig holder in the following) on the $\mathrm{x}$-ray unit. The reference surface is pressed against three preadjusted points of contact consisting of small steel balls on the jig holder.

The jig holder and the $\mathrm{x}$-ray collimator were mounted on an optical bench during the preadjustment. An optically flat vacuum-deposited aluminum mirror was pressed against the three points of contact on the jig holder. A laser beam was sent through the collimator. The position of the mirror was adjusted until the laser beam was reflected back upon itself. In this way the surface defined by the three points of contact was adjusted perpendicular to the line defined by the $x$-ray collimator to within $0.02^{\circ}$.

Once the jig holder is properly adjusted, it can be used for $x$-ray orientation of a sample mounted in the polishing jig. The sample is tilted by the adjustment screws of the jig until the desired crystallographic plane becomes perpendicular to the incident $x$-ray beam. In this position the crystallographic plane will also be parallel to the reference surface of the jig. The sample is then lapped and optically polished on a lapping machine. The orientation of the sample with respect to the reference surface can be checked and corrected if necessary throughout the whole procedure. The flatness of the reference surface and the prepared sample surface is checked in interferograms taken with sodium light using a quartz reference flat.

Figure 2 shows a Laue pattern of a $\{100\}$ silicon crystal slice. There is a perfect intensity symmetry of the characteristic line spots. Comparing with the earlier results. ${ }^{1}$ it can be concluded that the $\{100\}$ plane is perpendicular to

Fig. 2. Laue back reflection pattern of $\{100\}$ silicon crystal slice. The crystal is properly oriented with the $\{100\}$ plane perpendicular to the incident beam. Mo radiation, $50 \mathrm{kV}, 10 \mathrm{~mA}$. The characteristic line spots appear with greatly increased intensity compared with the average. Notice their symmetry in position as well as intensity.

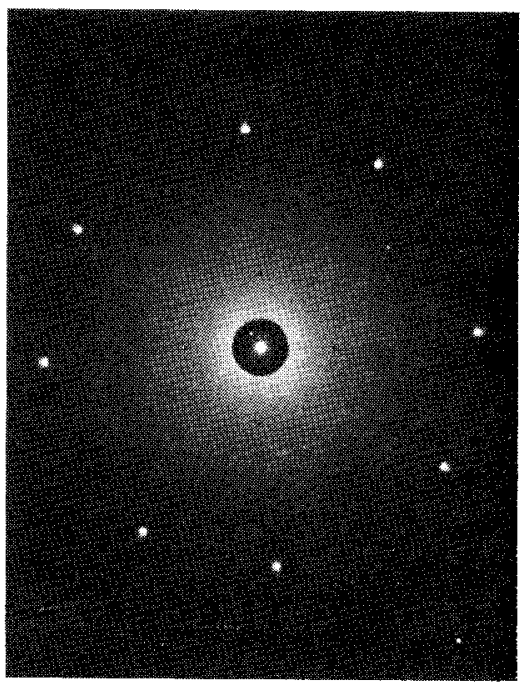


the incident $x$-ray beam within $0.01^{\circ}$. Identical Laue patterns were obtained before and after the polishing procedure.

The total uncertainty in the orientation of a sample arises from the uncertainties in the optical preadjustment of the jig holder and in the x-ray orientation of the sample. It follows from the above that the main contribution is due to the optical preadjustment in our case. The total uncertainty will be close to $0.02^{\circ}$.

\section{ACKNOWLEDGMENTS}

The authors wish to thank A. Lindegaard Andersen for his interest and comments. They are also indebted to Annie Langberg, Physics Laboratory III, for assistance in the laser beam alignment and advice concerning the polishing procedure.

'S. Ipsen Mathiesen, Rev. Sci. Instrum. 39, 1771 (1968). 